\title{
Announcing Business Communication Quarterly
}

Business Communication Quarterly is a refereed journal devoted to the teaching of business communication, which is a broad, interdisciplinary field. It is also international, and thus the journal aims to present the field from that international perspective. The journal publishes the following types of articles:

- discussion of issues and methods for teaching business communication in a variety of settings: two-year college, technical institute, four-year college, university, corporate or agency training program, and the like

- case studies of specific classroom techniques

- tutorials on business communication processes or products, especially innovations in electronic technology that need to be introduced into the classroom

- research on classroom teaching or assessment

- summary reviews of literature on teaching business communication

- book reviews - reviews of both textbooks and other items of interest to teachers

- reports on strategies for program development

The Business Communication Quarterly is published four times each year (March, June, September and December) by the Association for Business Communication. Regular $A B C$ membership is us $\$ 60$ annually; membership for full-time students is us $\$ 20$. Membership includes subscriptions to the Business Communication Quarterly and the Journal of Business Communication. The library subscription rate for the Quarterly is us $\$ 60$.

Further publishing and subscription information for Business Communication Quarterly can be found at this website: www.bcq.theabc.org

Editors' note: Technostyle and BCQ editors wish to share information about the other's publication with the hope of benefiting both readerships. 